\title{
IMPACT OF CLIMATE CHANGE RELATED POLICIES ON THE SECTOR OF GREEN JOBS
}

\author{
Z. Stoyanova* \\ Natural Resource Economic Department, Business Faculty, University of National and World \\ Economy, Sofia, Bulgaria
}

\begin{abstract}
Policies concerning the sector of green jobs on European level are related mainly to environmental protection, as well as those for clean energy and climate change. They require the application of policies for developing the sector of renewable energy and measures to reduce greenhouse gas emissions by creating new sustainable jobs. The aim of the paper is based on the review and analysis of policies related to climate change, to assess their impact on the sector of green jobs. The first part of the paper presents a review of climate change policies and an assessment of their impact on the creation of green jobs. The second part of the paper includes general conclusions about the role of policies related to climate change for the sector of green jobs.
\end{abstract}

Key words: green professions, climate change mitigation

\section{INTRODUCTION}

Policies governing the sector of green jobs at EU level are directly related to the policies for clean energy and climate change. This leads to growth in the subsector of renewable energy sources and implementation of measures for reducing greenhouse gas emissions by creating new sustainable jobs.

The European Union imposes climate change policies, which can be identified as a key factor in overcoming and fixing problems of the global climate. Simultaneously labour relations and social dialogue between different social groups play a significant role by fight with climate change.

The aim of the paper is based on the review and analysis of policies related to climate change, to assess their impact on the sector of green jobs.

Green jobs are created in the EU, mainly as a result of environmental solutions related to the fight against climate change (1). In this background, the priority sectors for creation of green jobs are the sectors of the renewable energy, sustainable transport and housing with low emissions of carbon dioxide. The public

\footnotetext{
*Correspondence to: Zornitsa Stoyanova, Bulgaria, Sofia, Studentski grad, ul. Hristo Botev, +35928195460,e-mail: zstoyanova@unwe.bg
}

sector should give the utmost support to these sectors during the transition period. Fluctuating policies, unstable and inconsistent legislative framework are the main constrains for development of main activities such as to create good and qualitative green jobs (2).

Green jobs differ significantly from the traditional professions. In most European countries, new green jobs are directed to sectors of renewable energy, construction, energy efficiency, waste and transport. Each country creates its own list of professions according to countries classification (3). The climate change policy and employment policy set environment unfriendly professions in unfavorable position in their employment plans. According to European Economic and Social Committee (2), there is a real risk that unemployment would be doubled in a short period without appropriate employment policies. In this context, the Social Committee suggest following activities:

- $\quad$ Ensure employment through initiatives aimed to creating new jobs to replace those which will be closed.

- Observing the relationship between new created and closed jobs.

- Implementation of appropriate forms which will support the mobility of workers. 
REVIEW AND ANALISYS OF CLIMATE CHANGE RELATED POLICYS

Measures for cope the climate change are related to the reduction of greenhouse gas emissions, adaptation to climate change and to fund problem for fixing climate change in developing countries. Simultaneously they are connected as well with development of low carbon technologies and transport system with low carbon emissions, forest protection, agriculture etc. It will appear the need for creation of green jobs with the development of new activities and sectors relating to fight with climate change.

Action on climate change will impact direct or indirect of creating green jobs. This is the area in which the EU is very active in recent years. In the policy documents can be defined two groups. Each group has different time period for setting up and achieving its own objectives. First period set up goals in variety of documents which implementation should be achieved up to 2020 . The main initiatives are as follows:

The European Economic Recovery Plan (November 2008). It has a direct impact on the sector of green jobs through one of the strategic objectives of the plan, which is the transition towards a low-carbon economy and creating green jobs. This goal requires: "Speed up the shift towards a low carbon economy. This will leave Europe well placed to apply its strategy for limiting climate change and promoting energy security: a strategy which will encourage new technologies, create new 'green-collar' jobs and open up new opportunities in fast growing world markets, will keep energy bills for citizens and businesses in check, and will reduce Europe's dependence on foreign energy". (4) The aims of this document, connected with climate change impact on the sector of green jobs through ideas for improving the energy efficiency of housing and public buildings, promote the implementation of green products. Other aims are connected with sectors of research and innovation by developing clean technologies and to improve security of energy supply.

Climate change package (December 2008). It includes six proposals to achieve the "20-20-20 goal" by 2020. Directive 2009/28 on climate change offers several options for improving energy efficiency and conservation of energy sources. Along with activities to fight with climate change, the Energy package 20-20-20 of the European Commission provides the creation of one million new jobs in the EU for the next decade only in the sector of renewable energy sources. Climate change package has a direct impact on the sector of green jobs: "The net effect consists of the creation of jobs (directly and indirectly) in certain sectors and the reduction of jobs in other sectors". For the EU a reduction of GHG emissions from $20 \%$ to $30 \%$ is expected to create a further stimulus for employment in the renewable sector and in energy efficiency sectors (5). International labour organization (ILO) explores three challenges linked to a transition to a green economy from labour market's point of view: 1. Economic restructuring; 2 . Climate change and threat to jobs and livelihoods; 3 . Adverse income distribution effects originating from energy poverty (6). Policies for renewable energy have the highest impact in terms of the creation of green jobs, because 7.36 million jobs were created in the EU in the field of renewable energy, energy efficiency, rehabilitation, organic farming waste management and recycling.

Europe 2020 strategy (March 2010). This is a document that includes legal requirements how to achieve the $20 \%$ reduction of greenhouse gas emissions and improving energy efficiency by $20 \%$ in all EU Member States. This commitment is one of the headline objectives of the growth strategy Europe 2020 and is implemented through a package of binding legislation (7). The objectives in the Strategy direct Europe to become very energy efficient economy by reaching low carbon emissions. As a result of the various directives arising from the Europe 2020 are created new green jobs.

$>\quad 2012$ Energy Efficiency Directive (October, 2012). It provides mandatory measures for energy efficiency of public buildings, including their renewal, schemes for saving of energy by energy companies and energy audits for all large enterprises. It set up rules designed to remove constrains in the energy market and protect from market failures that constrains efficiency in the supply and use of energy. It provides the establishment of indicative national energy efficiency objectives for 2020. The Directive also provides saving schemes for companies supplying energy. The companies covered by the directive would have to achieve "cumulative savings of final energy consumption". For this purpose, companies must achieve savings at least equivalent to $1.5 \%$ of annual energy sales to final consumers for each year between 2014 to 2020 (8). Energy used in transport sector could be excluded in case of creation of alternative ways to achieve equivalent energy 
savings. EU member states will have to support the creation of similar instruments or use of existing ones. The EU must take action to achieve the 2020 goal of saving $20 \%$ of main energy consumption compared to projections. Energy efficiency is one of the most cost-effective ways to enhance security of energy supply and reduce of greenhouse gases and other pollutants. In many ways, energy efficiency can be seen as the largest energy source in Europe. It includes an indicative target of $20 \%$ energy savings. Activities provided in the directive are the source of new jobs and this reduce costs for businesses. It includes an idea that there is need to improve the competitiveness of EU industry with the potential to create up to 2 million jobs.

The recovery plans of Member States. Impact on the sector of green jobs and climate change could be a result of the implementation of recovery plans of Member States. Most often, they include policies in sectors as energy efficiency, renewable energy sources, public transport and infrastructure. The percentage of the budget allocated to achieve green goals depends on the provided environmental friendly measures taken by each Member State. Percentages of green measures vary from $1.3 \%$ in Italy, to $13 \%$ in Germany, and $21 \%$ in France. The promotion of green jobs was specifically selected as a focus area of the national economic recovery plans of Greece, Ireland and the United Kingdom (7).

The second reviewed period in the paper is long term. It includes set of documents which should achieve their goals till 2050. Some of the main initiatives in these documents are as follows:

$\checkmark$ Roadmaps 2050 for a Resource Efficient Europe. The Commission's initiative provides a long-term framework for activities in various policy areas, but most of the initiatives related to climate change as a consequence of which is expected creation of large numbers of jobs in the green sector. Some of the policies are connected with the sectors of energy, transport, industry and others. Roadmap 2050 for a low carbon economy is founded on achieving the goal to reduce emissions by $80-95 \%$ till 2050 . Roadmap gives direction for realizing the transition to low carbon emissions over the next decades of sectors which cause emissions in Europe (energy, industry, transport, buildings and construction). The ideas of development of low-carbon economy are associated with increased production of renewable energy, use of energy-efficient building materials, development of green transport etc. According to some researches (7), in the economic could be created 1.5 million new jobs through increasing the activities connected with the climate change mitigation. The Energy Roadmap 2050 aims to develop an energy sector with low carbon emissions and gives the direction on how to achieve this without disruptions of energy supplies and without reducing the competitiveness. Roadmap for Europe 2050 for effective use of resources supports the transition to a resource efficient, low carbon economy to achieve sustainable growth. Efficient use of resources will lead to increased competitiveness and new sources of growth and jobs through cost savings from improved efficiency, implementation of innovations and better management of resources throughout their life cycle. The study provided in Germany shows that increasing resource efficiency in manufacturing could generate cost savings of between $20 \%$ and $30 \%$ and to create 1 million jobs in the country (7)

Strategy for a competitive transport system. The European Commission adopted in 2011 a strategy to increase mobility, remove major constrains in key areas and employment growth. An objective of the Strategy is related to reducing carbon emissions in transport by $60 \%$ till 2050. Figure 1 presents some of the targets of the strategy. According the implementation of the Strategy could be expected some of the following impacts:

1. Decarbonisation of transport will have a positive impact on the sector of green jobs;

2. The development of the automotive and transport sector would be an incentive to increase of employment in the green sectors (eco-industry, recycling, renewable energy).

\section{ANALISYS OF GREEN JOB SECTOR AND RELATED CLIMATE CHANGE POLICY}

The process of creating many green jobs is observing in the EU-countries. Green jobs are created in the EU, mainly as a result of environmental solutions related to the fight against climate change. In most European countries, the new green jobs are directed to sectors of renewable energy, construction sector, energy efficiency, waste, restoration and conservation of biological diversity, the development of green infrastructure and transport. Each country makes own rules what exactly is a "green profession" and what requirements have to obtain one working place to be called "green"(1). 


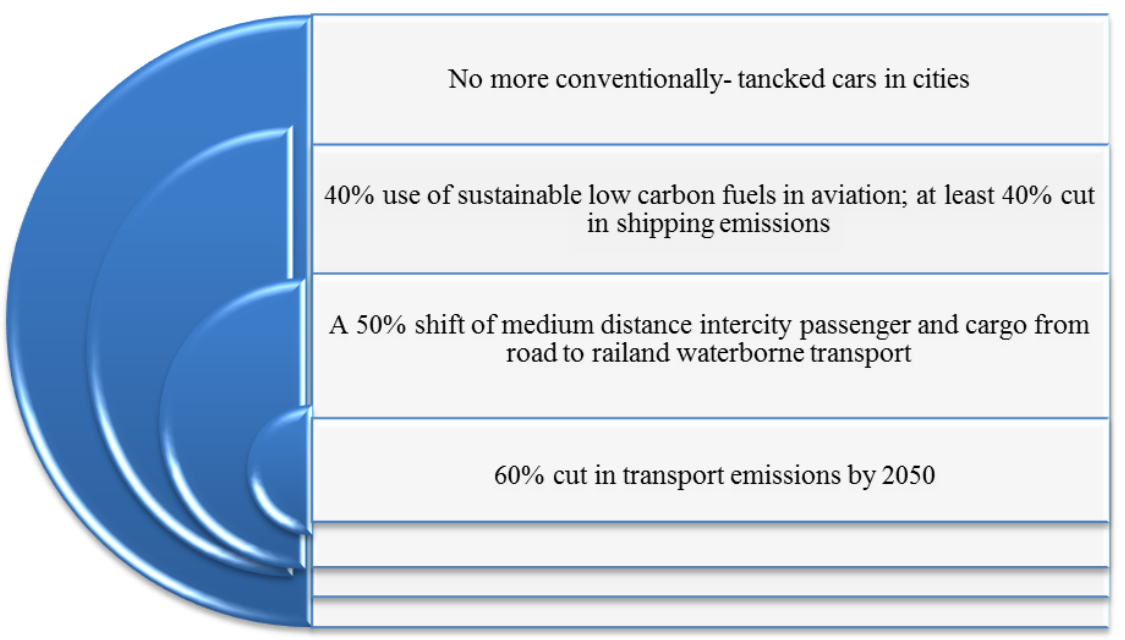

Figure 1. Targets including in Strategy for a competitive transport system

The potential for job creation due to implementation of climate change policy is linked to the production of renewable energy, energy efficiency, waste management, air quality, the development of green infrastructure. Most of the green jobs contribute to reduce negative impact of climate change and they are created due to the implementation of policies related to climate.

There is a trend of arising of new green jobs at European level as a result of the implementation of environmental policies particularly climate change policy. Figure 2 presents new green professions in sectors connected with climate change mitigation in EU. Green jobs that are created in recent years are mostly new professions. In many cases, these new green occupations are having employments as engineers, researchers, coordinators, operators etc. in green sectors of the economy (9).

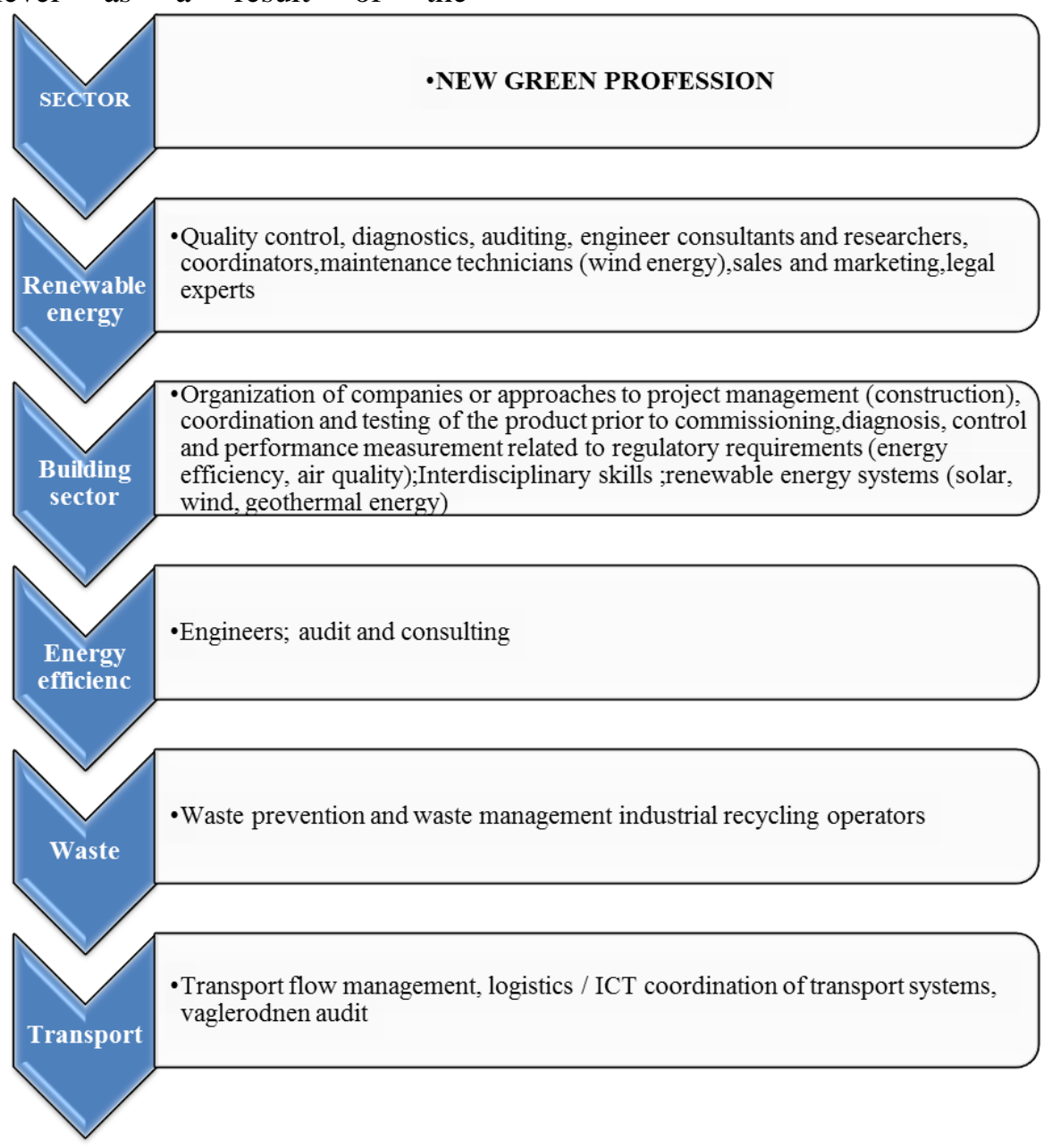

Figure 2. New green professions in key sectors of the EU economy 
Table 1 presents the climate change dimension to economic stimulus plans in EU and in some member-states. Data shows that $58.7 \%$ of the green fund is used for achieving objectives set in Economic recovery plan which is connected also with climate change and development of low-carbon economy. The funds in EU are allocated as follows: $54,8 \%$ for Carbon capture and storage; $21.3 \%$ for Grid; $12.5 \%$ for
Building energy efficiency; $8,5 \%$ for Vehicles; 2, $9 \%$ for Renewable energy. Germany is the country with the highest green fund budget - USD 13.8 bn and $75.3 \%$ from the fund is used for financing activities in Building energy efficiency. France along with the European Union is the country with highest fund for renewable energy - USD $0.87 \mathrm{bn}$, or $12.25 \%$ of the green fund.

Table 1. The climate change dimension to economic stimulus plans in Europe, billion USD

\begin{tabular}{|l|l|l|l|l|l|l|l|l|l|l|}
\hline Country & Package & $\begin{array}{l}\text { Green } \\
\text { fund }\end{array}$ & $\begin{array}{l}\text { \% } \\
\text { green } \\
\text { fund }\end{array}$ & RE & CCS & BEE & Veh & Rail & Grid & W/W \\
\hline EU & $\begin{array}{l}\text { Economic } \\
\text { Recovery } \\
\text { Plan }\end{array}$ & 22.8 & 58.7 & 0.65 & 12.49 & 2.85 & 1.94 & & 4.85 & \\
\hline Germany & Stimulus plan & 13.8 & 13.2 & & & 10.39 & 0.69 & 2.75 & & \\
\hline France & Revival Plan & 7.1 & 21.2 & 0.87 & & 0.83 & & 1.31 & 4.13 & \\
\hline Italy & $\begin{array}{l}\text { Emergency } \\
\text { Package }\end{array}$ & 1.3 & 1.3 & & & & & 1.32 & & \\
\hline Spain & $\begin{array}{l}\text { Stimulus } \\
\text { package }\end{array}$ & 0.8 & 5.8 & & & & & & & 0.83 \\
\hline UK & $\begin{array}{l}\text { Green } \\
\text { stimulus with } \\
\text { Loan for cars }\end{array}$ & 2.1 & 6.9 & & & 0.29 & 1.38 & 0.41 & & 0.03 \\
\hline $\begin{array}{l}\text { Other EU } \\
\text { states }\end{array}$ & $\begin{array}{l}\text { Stimulus } \\
\text { Package }\end{array}$ & 6.2 & 2 & 1.9 & & 0.4 & 3.9 & & & \\
\hline
\end{tabular}

RE - Renewable energy; CCS- Carbon capture and storage; BEE- Building energy efficiency Vech-Vehicles

W/W- Water/Waste

Source: (10)

The number of green jobs in key sectors connected with climate change mitigation is presented on Table 2. The data shows that, efficient transport and sustainable mobility followed by eco-industries, waste management and recycling and renewable energies are the sectors where more jobs have been created. In 2020 each of the sectors of waste and recycling and renewable energy will create more than 2 million green jobs.

Table 2. Green jobs in EU by sectors connected with climate change policy

\begin{tabular}{|l|c|c|c|}
\hline Green sector & Existing green jobs & $\begin{array}{l}\text { Potential for green } \\
\text { jobs creation in 2020 }\end{array}$ & $\begin{array}{l}\text { Potential for green jobs } \\
\text { creation in 2050 }\end{array}$ \\
\hline Eco-industries & $\begin{array}{c}2900000-3600 \\
000 \\
(2008)\end{array}$ & - & - \\
\hline $\begin{array}{l}\text { Energy efficiency in } \\
\text { buildings }\end{array}$ & $\begin{array}{c}232050 \\
(2008)\end{array}$ & $261400-378000$ & - \\
\hline Renewable energy & $\begin{array}{c}114210 \\
(2010)\end{array}$ & 2700000 & 6100000 \\
\hline $\begin{array}{l}\text { Efficient transport \& } \\
\text { sustainable mobility }\end{array}$ & 3900000 & - & - \\
\hline $\begin{array}{l}\text { Waste \& recycling } \\
\text { sector }\end{array}$ & $\begin{array}{c}2000000 \\
(2008)\end{array}$ & $2400000-2963000$ & - \\
\hline Sourc adp & & & \\
\hline
\end{tabular}

Source: adapted (7)

The reviewed policy of green jobs as well can be summarized on National level. Bulgaria is EU member state since 2007 and as well is adopting measures which will bring positive impact on the climate. The package which includes employment measure is applied in
Bulgaria since 2011. In it green jobs are those types of employment which leads after it sustainability. The follow information tracks the state of development in Bulgarian green jobs, their sectors, distribution and professions. 
Figure 3 is showing rapidly decreasing trend of green jobs in Bulgaria. During the period since the measure was adapted (2011) the number of green jobs are reduced almost three times and reached bottom of 276 (2014) of which 100 are new created places. This negative trend can be explained with very high requirements on one hand for the employers and on other hand very low payment for the employees. This makes the measure not attractive.

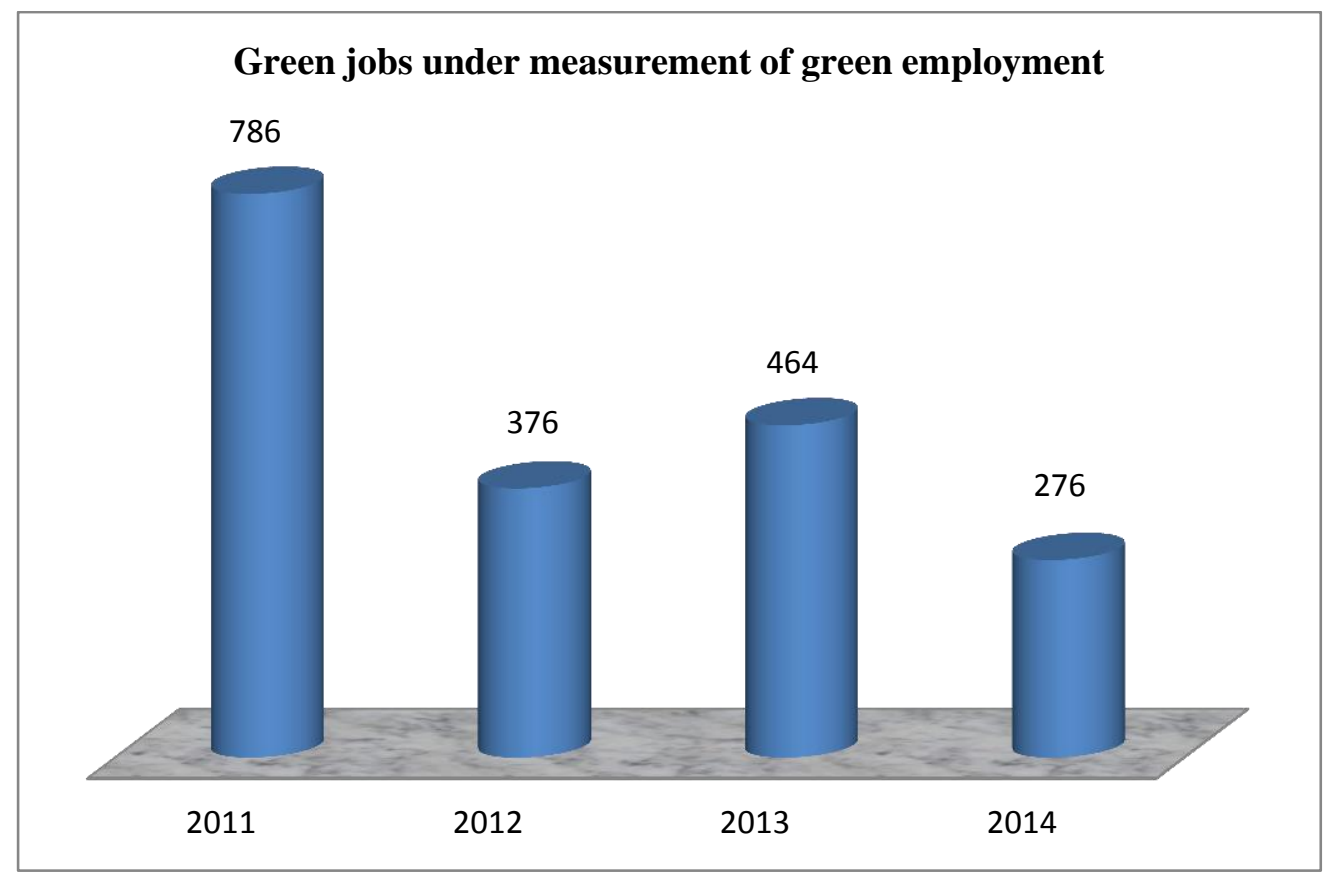

Figure 3. Green jobs under measurement of green employment in Bulgaria

Table 3 presents the employers who employed people under the measure for green jobs in the period 2011-2014. They are in the following sectors: Section C: Manufacturing; Section D: Production and distribution of electricity, heat and gaseous fuels; Section E: Water supply, sewerage, waste management and recovery; Sector F: Construction of hydraulic equipment; Section N: Administrative and support service activities. The employer's number who used green jobs measure for the period 2011-2013 is almost permanent. Around $80 \%$ of the employers operate in the section $\mathrm{E}$ and could be explain with the most common green profession in Bulgaria like landshaft specialist, landscaper etc. On second place are the companies operating in section $\mathrm{F}$ and $\mathrm{D}$. In 2013 the percent of the companies created green jobs in these sectors are 7.3 and $4.3 \%$.

Table 3. Number of Employers used the green jobs measure in Bulgaria by sections

\begin{tabular}{|c|c|c|c|c|c|c|c|c|}
\hline \multirow[t]{3}{*}{ Sector } & \multicolumn{8}{|c|}{ EMPLOYER } \\
\hline & \multicolumn{2}{|c|}{2011} & \multicolumn{2}{|c|}{2012} & \multicolumn{2}{|c|}{2013} & \multicolumn{2}{|c|}{2014} \\
\hline & Number & $\%$ & Number & $\%$ & Number & $\%$ & Number & $\%$ \\
\hline C & 1 & 1.8 & 2 & 3.9 & 3 & 4.3 & 1 & 3.1 \\
\hline D & 3 & 5.6 & 2 & 3.9 & 3 & 4.3 & 1 & 3.1 \\
\hline $\mathbf{E}$ & 45 & 83.3 & 43 & 84.3 & 55 & 79.8 & 25 & 78.2 \\
\hline $\mathbf{F}$ & 3 & 5.6 & 3 & 5.9 & 5 & 7.3 & 4 & 12.5 \\
\hline $\mathbf{N}$ & 2 & 3.7 & 1 & 2 & 3 & 4.3 & 1 & 3.1 \\
\hline Total & 54 & 100 & 51 & 100 & 69 & 100 & 32 & 100 \\
\hline
\end{tabular}

Source : (11-14)

\section{GENERAL CONCLUSION AND POLICY RECOMMENDATION}

Based on the analysis of green jobs sector and related climate change policy are made general conclusions as follows:

$\checkmark \quad$ Climate change policies which have a significant role in coping problems of global climate are the key factor for growth of green jobs creating sustainable jobs in sectors of renewable energy, sustainable transport, houses with low emissions of carbon dioxide etc.

$\checkmark \quad$ Climate change aims influences on the sector of green jobs by implementing energy 
efficient public and private sector. The impact is related to increased interest of the society to "green" products.

$\checkmark$ There is a risk for increasing unemployment due to climate change and employment policies. Therefore policy makers have to pay attention to ensure employment through initiatives aimed at creating new jobs which will replace the closed jobs in environment unfriendly sectors and to support the mobility of workers.

Two groups of policy documents could be identified according to the period for which they need to achieve the objectives set out in them. Some of the documents as European Economic Recovery Plan, Climate Change package, Europe 2020 strategy have a direct impact on the sector of green jobs, other as Energy efficiency Directive; Roadmaps 2050 for a Resource Efficient Europe have an indirect impact.

$\checkmark \quad$ Climate change related policies influence on the sector of green jobs through creating new sustainable jobs in sectors as energy efficiency, renewable energy sources, public transport etc.

$\checkmark \quad$ New green professions as engineers, researchers, coordinators, operators in green sectors arise at EU level as a result of the implementation of climate change related policies.

$\checkmark \quad$ The highest amount from the green fund at EU level is linked to carbon capture and storage. The highest green fund budget is planned in Germany and France is the country with highest fund for renewable energy.

$\checkmark \quad$ Efficient transport and sustainable mobility followed by eco-industries are the sectors which created more jobs than another, but in future aspect sectors of waste and recycling and renewable energy will create more than two million green jobs.

$\checkmark \quad$ The number of created green jobs in Bulgaria for the period 2011-2014 is decreasing. This negative trend could be explained with very high requirements on one hand for the employers and on other hand very low payment for the employees.

$\checkmark \quad$ The employer's number who used green jobs measure for the period 2011-2013 is almost permanent. Most of them $80 \%$ operate in the section E - Water supply, sewerage, waste management and recovery and this could be explain with the most common green profession in Bulgaria like landshaft specialist, landscaper etc.

\section{REFERENCES}

1. Stoyanova, Z., Harizanova, H. Perspectives of development of green jobs in Bulgaria. Economics of agriculture, issue no. 2/2015, 2015.

2. European Economic and Social Committee. Statement for Promoting sustainable green jobs in order the package of EU measures in the field of energy and climate change. Brussel, 2010.

3. Harizanova H. State and development of green jobs in EU. Jornal Management and sustainable development, 2015.

4. EU. A European Economic Recovery Plan. Brussels, 2008.

5. EU. Analysis of options to move beyond 20 $\%$ greenhouse gas emission reduction and assessing the risk of carbon leakage. Background information and analysis. Part II, Brussels, 2010.

6. ILO. Sustainable development, decent work and green jobs. Geneva, 2013.

7. Sustainlabour. An overview of the European Union: Green Jobs and related policy frameworks. Madrid, 2013.

8. European Parliament and Council. Directive 2012/27/EU on energy efficiency. Official Journal of the European Union, 156, 2012.

9. Miteva, A., Stoyanova, Z., Harizanova, H., Peicheva, M., Doichinova,J.,Kanchev,I. Green jobs - tool of ecologisation of Bulgarian Economy, Research project, NID NI1-6/2014, University of national and world economy, Sofia, Bulgaria, 2014.

10.Robinson, N., Clover, R., Singh, Ch. HSBC Global Research "A climate for Recovery”, HSBC Bank plc., 2009.

11.Employment agency, Information for realization of promoting measure according article $55 \mathrm{~d}$ from Low of promoting employment, 2011.

12.Employment agency, Information for realization of promoting measure according article 55d from Low of promoting employment, 2012.

13.Employment agency, Information for realization of promoting measure according article $55 \mathrm{~d}$ from Low of promoting employment, 2013.

14.Employment agency, Information for realization of promoting measure according article 55d from Low of promoting employment, 2014. 